\title{
Inclusive Economic Development Model as the Alternative of Sustainable Social-Economy Engineering -a Case of Tourism-Based Social Economy Development in Wakatobi Regency
}

\author{
Yuanita Indriani \\ Rima Elya Dasuki \\ Yeni Wipartini
}

\begin{abstract}
Basically, inclusive economy development is the economy development contributing to majority of people in Indonesia aiming to poverty reduction. In the situation where the challenges become more complicated, the tourism development could be directed to the inclusive economy development based on tourism. It supports tourism growth centers. This enables to get inequality income and poverty reduction through pro poor tourism. This research uses an action research through observation toward various aspects relating to the development of inclusive economy. The results of this research identify that integrated tour and travel businesses become prospective business; furthermore, handy craft, food and beverages industries. If it is related to SWOT Analysis and study of tourism market; also the perception of local people, the most crucial consideration in developing the tourism based inclusive economy in Wakatobi is a forming of synergy among the large businessmen and people business as well as all people supports. Therefore, all tourists visiting Wakatobi get pleasure and satisfied and the businessmen get more and better benefits and profit. Another result shows that action to synergize businessmen is required to vague conflicts causing and occurring unhealthy competition. The creating of among-businessmen synergy is derived to be business model of tourism based associate-businessmen in Wakatobi Regency. The early step of the development of tourism based inclusive economy is conducted well, however there are some constrains to be considered to maintain and develop the formulated model and for that, risk assessment could be used.
\end{abstract}

Keywords: inclusive economy, sustainable development, business model and social-economy development

\section{Introduction}

\subsection{Background}

Inclusive economic development is essentially economic development that can contribute to the majority of the people, including leading to the eradication of people's poverty. In this case, inclusive economic growth must be built on three main pillars: maximizing economic opportunities, providing social safety nets, and ensuring equal access to all economic opportunities.

To respond to the increasing and the more complex challenges, tourism development can be directed to tourism-based inclusive development in tourism area, namely the development of a tourism economy that contributes to the wider community by encouraging the tourism growth centers, tourism business units, SMEs, and employment hired in Tourism destination in order to reduce income inequality and poverty alleviation through tourism (pro poor tourism).

Pioneering tourism-based inclusive development is conducted to creating a document planning and a tourism business model involving local and low-income communities. While the goal is to provide development direction and strategic tourism business management, in accordance with the characteristics and excellence of tourism in the area.

\subsection{Research Question}

1) How the tourism based business atmosphere in the Study Area, including: type of business, the number of labor, turnover, business competitiveness, and business institutions;

2) How tourism market demand which are not available yet in the study area;

3) How are the potentials, problems, and strategic issues of inclusive tourism-based development; 
4) How the inclusive tourism development model;

5) How the business incubation model from low income local people.

6) How the commercialization of the business developed so that resulting product can be well informed to the market.

\subsection{Research Goals}

1) Map of the tourism based business atmosphere in the Study Area, including: type of business, the number of labor, turnover, business competitiveness, and business institutions;

2) Map of tourism market demand which are not available yet in the study area;

3) Analysis on potentials, problems, and strategic issues of inclusive tourism-based development;

4) Inclusive tourism-based development model;

5) Business development model of local people with low income;

6) Commercialization model of the business developed.

\section{State of The Art}

Action Research, triggered by the phenomenon that occurred in the tourism sector. The facts show that in general the tourism sector is growing rapidly, but local people are not the main players, they are only a small part, less important and easily replaceable due to lack of competence and capital. Business in the field of tourism that develops in an area generally controlled by the owners of capital and usually a newcomer. Indications that lead towards will happens in Wakatobi, a district that is very potential to be developed as the world's coral triangle, which became the center of attention as well as a major destination of divers from all over the world. To create and build an inclusive tourism business, socio-economic engineering is required to the surrounding community, so that they can become a major competitive tourism based business, if it is not done, then tourism in Wakatobi Regency will develop similarly to tourism areas elsewhere, Where local people are just spectators.

The method used in this research is Action Research, with the technique of data retrieval directly through FGD forum, conducted in three stages as follows:

Table 1. FGD Stages and Its Goals Setting

\begin{tabular}{|l|l|}
\hline FGD & Goals Setting \\
\hline 1 st & $\begin{array}{l}\text { Mapping the tourism actual condition; } \\
\text { Mapping of community involvement in local tourism activities; } \\
\text { Potential of tourism development and community involvement therein; } \\
\text { People's hopes and / or concerns about tourism development. }\end{array}$ \\
\hline 2nd & $\begin{array}{l}\text { The direction of inclusive tourism-based development; } \\
\text { Involvement (function and role) of the community in the tourism based inclusive development; } \\
\text { Description of inclusive tourism development model. }\end{array}$ \\
\hline 3rd & $\begin{array}{l}\text { Completion of inclusive tourism-based development model; } \\
\text { Affirmation of the functions, roles, authorities and responsibilities of each tourism business actor in the tourism-based } \\
\text { inclusive development. }\end{array}$ \\
\hline
\end{tabular}

FGD results are formulated into decision points to serve as a basis for the completion of the next stage, as the next FGD material.

Sources of research data are person, books and previous research results that can explain the phenomenon under study in accordance with the actual conditions.

Resource person is set purposively with the following conditions:

1. Key person of local tourism based business;

2. Willing and able to share and work in group in order to enhance the potential resources (local people and local nature);

3. Representative of local people;

Stages and the process of taking data graphically can be seen in Figure 1. 


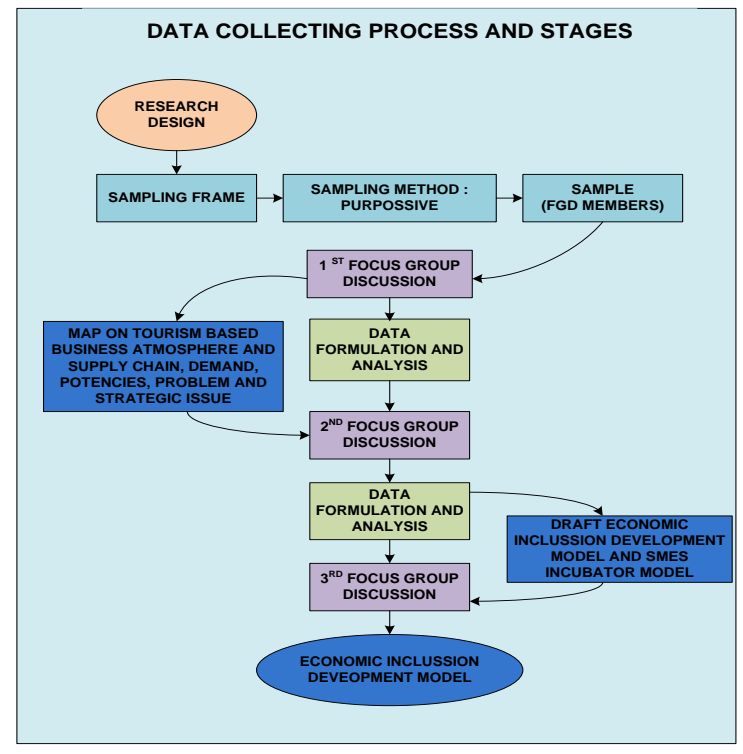

Figure 1. Data Collecting and analysis

\subsection{Data Analysis}

Data analysis is done descriptively, with the data retrieval stage as follows:

Table 2. Research Goals and Data Collecting Method

\begin{tabular}{|l|l|l|}
\hline No & Research Goals & Data Collecting Method \\
\hline 1. & Map on Tourism based business atmosphere & $\begin{array}{l}\text { On the spot Observation and Focus Group } \\
\text { Discussion, library research. }\end{array}$ \\
\hline 2. & Map on Local Tourism demand which are not set up yet & $\begin{array}{l}\text { On the spot Observation and Focus Group } \\
\text { Discussion; discussion with local government } \\
\text { and informal leader, library research. }\end{array}$ \\
\hline 3. & $\begin{array}{l}\text { Map of potencies, problems and strategic issue on Tourism based } \\
\text { inclusive business development }\end{array}$ & $\begin{array}{l}\text { On the spot Observation, Focus Group } \\
\text { Discussion, discussion with local government } \\
\text { and informal leader, library research. }\end{array}$ \\
\hline 4. & Tourism based Inclusive business development model & $\begin{array}{l}\text { On the spot Observation, Focus Group } \\
\text { Discussion, discussion with local government } \\
\text { and informal leader, library research. }\end{array}$ \\
\hline 5. & SMEs Incubator model & $\begin{array}{l}\text { Library research, On the spot Observation, } \\
\text { Focus Group Discussion, discussion with local } \\
\text { government and informal leader, library } \\
\text { research. }\end{array}$ \\
\hline 6. & Product commercialization & $\begin{array}{l}\text { Library research, On the spot Observation, } \\
\text { Focus Group Discussion, discussion with local } \\
\text { government and informal leader, library } \\
\text { research, actual and potential buyers }\end{array}$ \\
\hline
\end{tabular}

\section{Research Result}

\subsection{Tourism Business Atmosphere}

The results of the first FGDs indicate that the most appropriate tourism-based business field for entry into low-income communities can be illustrated in Table 3. 
Table 3. Decent Community Activities Developed in Inclusive Tourism

\begin{tabular}{|l|l|l|l|l|l|}
\hline \multirow{2}{*}{ C } & \multicolumn{5}{|l}{ Rank } \\
\cline { 2 - 7 } & I & II & III & IV & V \\
\hline Handicraft \& Traditional Art & 4 & 7 & 2 & 3 & 3 \\
\hline Transportation & 1 & 1 & 1 & 2 & 4 \\
\hline Attractions & 9 & 3 & 4 & 2 & 3 \\
\hline Home stay & & 1 & 2 & 5 & 2 \\
\hline Traditional Culinary & 2 & 2 & 6 & 1 & 2 \\
\hline Agriculture Product & & & & 2 & 2 \\
\hline Fisheries & & 2 & 1 & 1 & \\
\hline
\end{tabular}

The first FGD identified that the Business of Tourism Activity is a highly prospective business, followed by handicraft and food and beverage industries.

But in the first FGD also seen potential conflict among business actors, this became one of the factors that potentially lead to unhealthy competition among tourism-based business actors in Wakatobi.

The topic discussion of third FGD was the potential problem of unhealthy business competition, and its solution. The synergy among tourism-based business actors is expected to be a solution of the potential problem, which is also expected to strengthen the existence of local communities as the main actors of tourism-based businesses. Efforts to be pursued by tourism-based business actors in Wakatobi is done by gathering the entire potential of the Wakatobi community, which is in accordance with local wisdom.

The design of business synergy that support each other and strengthen business actors in Wakatobi, is revealed to be a business model of the Association of Wakatobi Tourism-Based Entrepreneurs, which can be illustrated as follows: The Wakatobi community's inclusive business model is conducted through the Wakatobi Businessmen Association, mapped based on the Canvas Business Model, as shown in Figure 3.

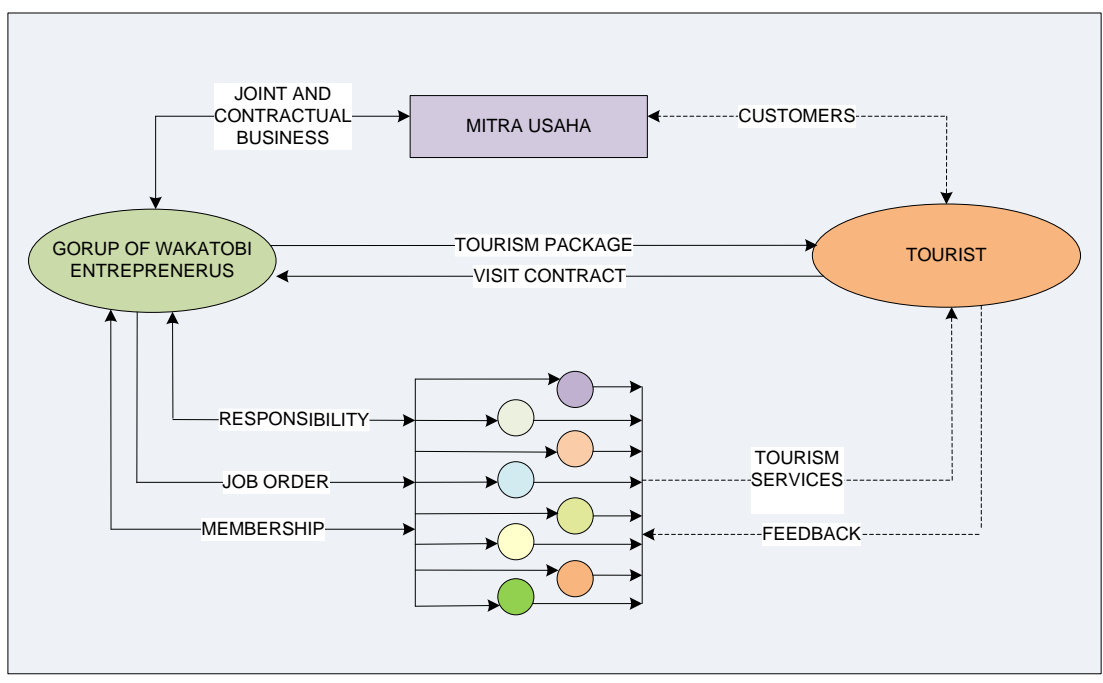

Figure 2. Joint Business Network Model of Wakatobi Tourism Based Business Entrepreneur

The business model of the Association of Wakatobi Tourism-Based Entrepreneurs, can be described as follows: 


\section{CANVAS BUSSINES MODEL ENTREPRENEURS GORUP OF WAKATOBI}

\begin{tabular}{|c|c|c|c|c|}
\hline 7. KEY PARTNERS & $\begin{array}{l}\text { 5. KEY } \\
\text { ACTIVITIES }\end{array}$ & $\begin{array}{l}\text { 1. VALUE } \\
\text { PROPOSITIONS }\end{array}$ & 3. CUSTOMER RELATIONSHIP & $\begin{array}{l}\text { 2. CUSTOMER } \\
\text { SEGMENTS }\end{array}$ \\
\hline $\begin{array}{l}\text { - Wings Air } \\
\text { - Garuda Indonesia } \\
\text { - PT Pelni } \\
\text { Big scale Hotel dan } \\
\text { Resort } \\
\text { - Tour Operator }\end{array}$ & $\begin{array}{l}\text { - Commitment of } \\
\text { Wakatobi entrepreneur } \\
\text { engaged in tourism } \\
\text { Local Government } \\
\text { - ICT support (Social } \\
\text { media network, data } \\
\text { base, handling } \\
\text { coordination) }\end{array}$ & $\begin{array}{l}\text { Safe, Valuable and } \\
\text { memorable tourism } \\
\text { experience }\end{array}$ & $\begin{array}{l}\text { Communication networks with customers } \\
\text { (including those in the data base) conducted } \\
\text { through social media (fb, IG, Path, Twitter, WA, } \\
\text { Line) are professionally managed, and ready to } \\
\text { offer travel packages according to tourists' wishes, } \\
\text { answer questions, deal Complain, provide custom } \\
\text { offers, and always maintain relationships with } \\
\text { potential tourists and who have been traveling to } \\
\text { Wakatobi. }\end{array}$ & $\begin{array}{l}\text { - Divers, } \\
\text { researcher of } \\
\text { marine biota } \\
\text { conservation, } \\
\text { - Upper and } \\
\text { Middle-class } \\
\text { tourists and } \\
\text { - Backpacker }\end{array}$ \\
\hline \multicolumn{3}{|c|}{ 8. COST STRUCTURE } & \multicolumn{2}{|l|}{ 9. REVENUE STREAMS } \\
\hline \multicolumn{3}{|c|}{$\begin{array}{l}\text { - Investment costs (Application system, equipment and machinery) } \\
\text { - Promotion Fee, } \\
\text { - Operational and maintenance expenditures }\end{array}$} & \multicolumn{2}{|c|}{$\begin{array}{l}\text { Revenues from fees for tourists services, donations and Government program } \\
\text { funds for marine biota conservation and other programs (National and } \\
\text { Regional), revenues from supporting business units (equipment rent, } \\
\text { workshop, guide, etc.) }\end{array}$} \\
\hline
\end{tabular}

Figure 2. Canvas Business Model of of Wakatobi Tourism Based Business Entrepreneur

Transformation Model of Wakatobi Tourism Based Business Entrepreneur can be describe as follow:

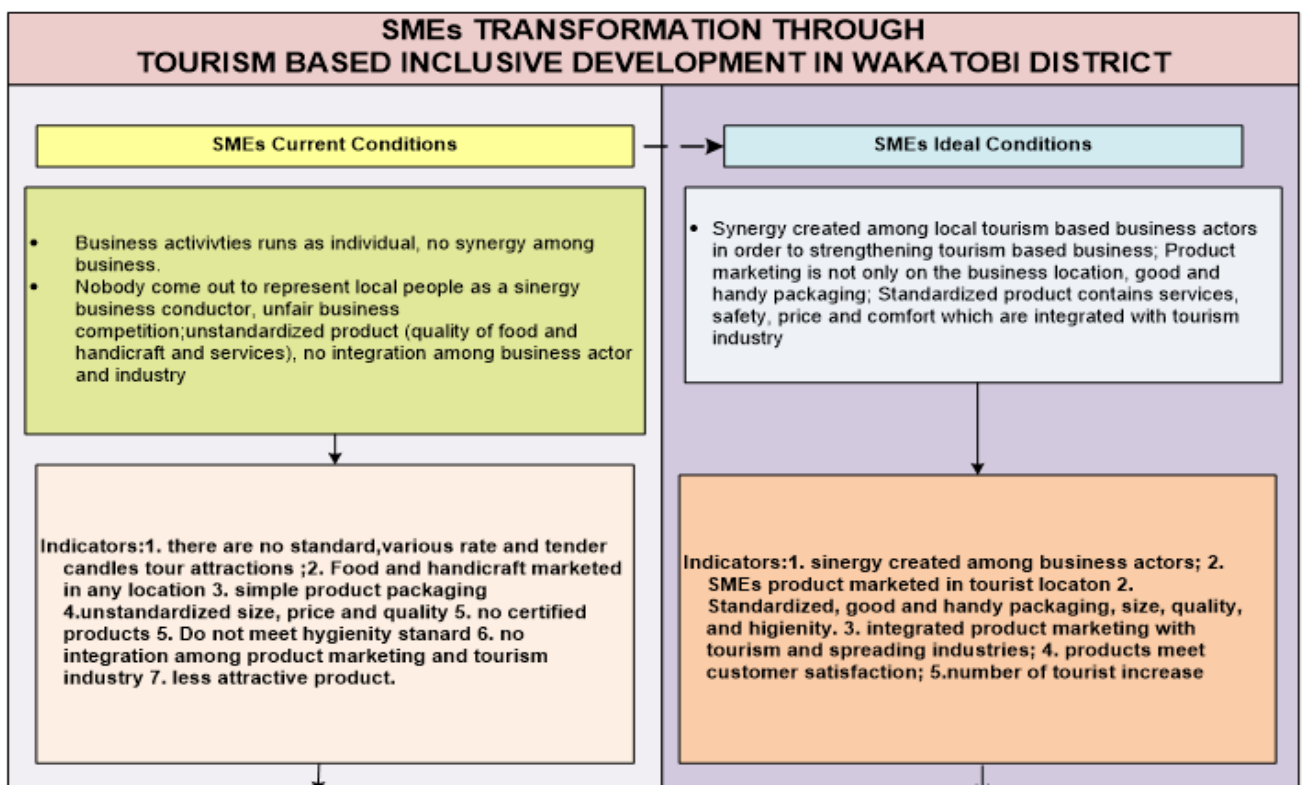




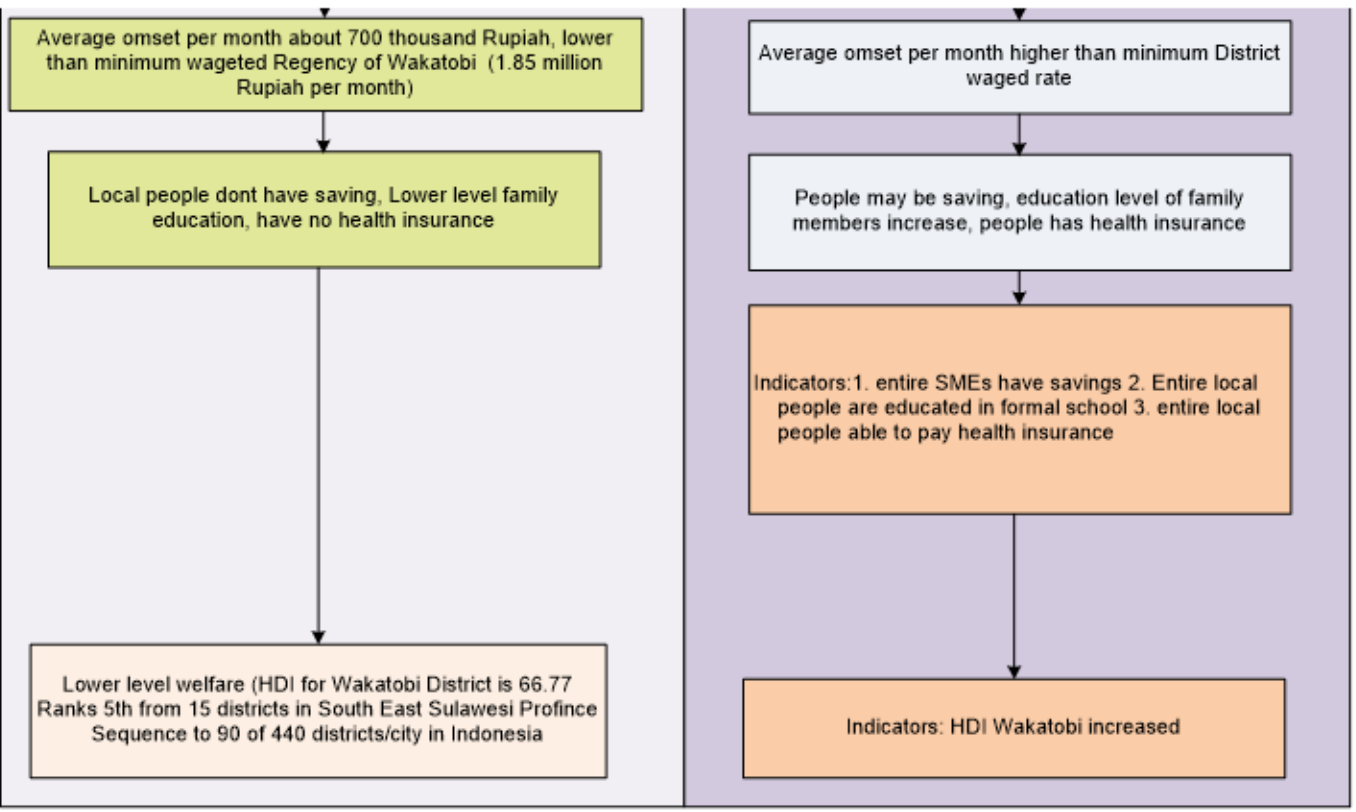

Figure 3. SMEs Transformation Through Tourism Based Inclusive Development In Wakatobi District

IV.

CConclusion and Recommendation

4.1.

Conclusion

1) This study is the base of inclusive tourism-based development activities, which is expected to have a very high impact on the successful implementation of inclusive economic development in the future, as this first phase of work will be the basis for the implementation of inclusive economic development in the next stage.

2) The early stages of inclusive tourism-based development in Wakatobi Regency have been well implemented, but there are still problems that need attention for the implementation of the next stage, this is outlined in the risk assessment of job implementation.

3) The potential of inclusive economic development in Wakatobi District is categorized as very high criterion, it is based on the habit of the people to dive and also act as local entrepreneur, entrepreneurship life is not something new for the local people. Cultural diversity creates a wide variety of culinary and uniqueness, which can be lifted into one of the tourist attractions, and the combination of marine and natural sports tours with culinary and crafts is utilized as a promising business potential.

4) Current tourist visits are key to the success of Wakatobi Regency's business community, as tourists are the market of various tourism products, so maintaining the continuity of tourist visits is a very urgent thing to do, the strategies undertaken are:

- Optimize the promotion of travel packages through multi-media multi-way and multi actors;

- Establish cooperation and partnerships with big businessmen and government in organizing events at provincial, national and international levels.

- Maintain the satisfaction of tourists visiting Wakatobi, with a charm as an indicator.

5) The orientation of inclusive economic development of SMEs target in Wakatobi Regency is more directed to the creation of regional and national international link, this is done by: establishment of network of business cooperation; Cooperation and synergy in seeking more attractive, better, safer and more comfortable tourism attractions and objects; Utilization of Wakatobi's souvenir center which is being initiated by the District Government, as well as marketing breakthrough of various products on-line and through tourist blogger. 
6) The commitment of Wakatobi District SMEs in the development of tourism-based inclusive is embodied in a follow-up plan that generally shows the seriousness and commitment of tourism-based SMEs.

7) Creating business synergies through the combined efforts of SMEs Wakatobi, in the form of Cooperatives ;

- Maintain a commitment to take advantage of the joint venture to create synergies among tourism-based business actors:

- Mutually strengthen tourism area by dividing into its characteristics.

\subsection{Recommendation}

1)This inclusive economic development program involves several government Institutions within Wakatobi District and Provincial level, it is deemed necessary to disseminate the program. This needs to be done to create synergies among government Institutions so that the Tourism Development Program of Inclusive Economy in Wakatobi Regency can run optimally.

2)District and / or Provincial Governments institutions may access various strengthening programs implemented by the National Government that are cross-ministerial (Ministry of Tourism, Ministry of Industry and Trade, Ministry of Cooperatives and SMEs, as well as other Ministries).

3)Policy and facilitation needs to be issued by the District Government requiring Hotel and other institutions to participate in marketing various products of SMEs.

4)To maintain the sustainability of the program, it is necessary to prepare the operational framework for monitoring and evaluation of each stage of implementation, complete with indicators of achievement. Nor are other relevant research, supporting the creation of socio-economic engineering models of society in inclusive development. 